\section{Nitrogen Management of Greenhouse Pepper Production: Agronomic, Nutritional, and Environmental Implications}

\author{
Hagai Yasuor ${ }^{1}$, Alon Ben-Gal, and Uri Yermiyahu \\ Gilat Research Center, Agriculture Research Organization, Rural delivery \\ Negev, 85280, Israel
}

\author{
Elie Beit-Yannai \\ Pharmacology Department and School of Pharmacy, Ben-Gurion University \\ of the Negev, Beer-Sheva, Israel
}

\section{Shabtai Cohen}

Negev Agricultural R\&D Center, Besor Experimental Station, 85400, Israel

Additional index words. Capsicum annuum, fertigation, fertilizer use efficiency, fruit quality, nitrate leaching

\begin{abstract}
Producers of horticultural products face new and growing standards regarding food quality and safety as well as environmental responsibility and sustainability. The objective of this research was to reduce environmental pollution by increasing nitrogen use efficiency (NUE) in vegetables without negatively affecting fruit yield or quality. Bell pepper was used as a case study for intensive vegetable cropping. Pepper cultivars with different vegetative vigor were drip-irrigated with solutions containing 9.2, 56.2, 102.3, and $158.5 \mathrm{mg} \cdot \mathrm{L}^{-1}$ nitrogen $(\mathrm{N})$. Fruit yield, quality, and nutritional value were measured. Nitrogen balance was determined by quantifying $N$ in soil and in plant tissues. Maximum yields were found when peppers were irrigated with $56.2 \mathrm{mg} \cdot \mathrm{L}^{-1} \mathrm{~N}$. Nitrogen concentrations of 102.3 and $158.5 \mathrm{mg} \cdot \mathrm{L}^{-1} \mathrm{~N}$ loaded 400 and $800 \mathrm{~kg} \cdot \mathrm{ha}^{-1} \mathrm{~N}$ into the environment, respectively, whereas for the $56.2 \mathrm{mg} \cdot \mathrm{L}^{-1} \mathrm{~N}$ concentration, $\mathrm{N}$ was almost completely taken up and used by the plants. Nitrogen treatments had no significant negative effect on pepper fruit physical or chemical quality parameters including sugar content and acidity. Reduced $\mathrm{N}$ application did not affect nutritional quality components of the pepper fruit such as $\beta$-carotene and lycopene content or total antioxidant activity. The vigorous cultivar used $N$ more efficiently. The results demonstrate how the environmental impact of intensive agriculture can be minimized without harming fruit yield or quality by reducing $\mathbf{N}$ application level and adopting cultivars with improved $\mathbf{N}$ use efficiency.
\end{abstract}

As a result of a rising demand for yearlong supply of fresh produce and the necessity of plant protection, the use of protective housing (insect-proof net houses and greenhouses) for cropping systems has gained global importance. Protected cultivation is particularly important for the production of fresh vegetables (Gruda, 2005). Improvements in agricultural practices in the past mainly focused on productivity; today, objectives including crop product quality, production cost, and environmental impact have

Received for publication 22 May 2013. Accepted for publication 30 July 2013 .

We thank Fertilizers \& Chemicals Ltd Israel for the fertilizer supply. We also thank Zeraim Gedera, Israel, for supporting the research. We thank Hanna Yehezkel and the Negev Agriculture R\&D Center staff for managing the experiments and Inna Feingold, Lyudmila Yusupov, Shoshana Suryano, and Janeta Orenstein for technical support.

${ }^{1}$ To whom reprint requests should be addressed; e-mail hagai@agri.gov.il. become fundamental. $\mathrm{N}$, the most important and widely applied agricultural nutrient, is also a major potential environmental contaminant and, hence, increasing NUE is central to environmental responsibility and agricultural sustainability (Fageria and Baligar, 2005; Gastal and Lemaire, 2002; MascleauxDaubresse et al., 2010). Improved N management has become essential in recent years because of increased levels of nitrate $\left(\mathrm{NO}_{3}\right.$ $\mathrm{N}$ ) in groundwater associated with high rates of $\mathrm{N}$ fertilizer application to crops (Del Amor, 2007). Sufficient $N$ is essential for normal plant growth and development, being an integral part of protein and chloroplast structure and function (Barker and Bryson, 2007). Nitrogen deficiency has been studied on the majority of horticultural crops, whereas the effects of oversupply of $\mathrm{N}$ are not as widely understood (Stefanelli et al., 2010). In vegetable crops, excessive $\mathrm{N}$ often leads to increased vegetative growth at the expense of root or fruit development (Elia and Conversa, 1998). In greenhouse tomatoes, high $\mathrm{N}$ can 2012; Mengel et al., 2001; Ruiz and Romero, lead to poor fruit set, to reduced sugars, and to consequential inferior taste (Stefanelli et al., 2010). The low cost of $\mathrm{N}$ fertilizers and the dramatic effect of $\mathrm{N}$ application on yields of intensive vegetable crops have led to overuse of fertilizers by farmers (Glass, 2003). For this reason, in many agricultural systems, a considerable proportion of applied $\mathrm{N}$ fertilizer is lost from the root zone to subsoil, groundwater, rivers, and oceans (Glass, 2003). Leaching of $\mathrm{NO}_{3}-\mathrm{N}$ occurs in many vegetable production areas where $\mathrm{N}$ application rates exceed crop demand (Zhu et al., 2005).

Pepper (Capsicum annum L.) production is becoming commercially important in various regions of the world including Israel, Spain, southern Europe, and north Africa where the crop is grown from fall to spring in greenhouses and net houses. Such production in protective structures commonly yields more than $100 \mathrm{t} \cdot \mathrm{ha}^{-1}$ of high-quality fruit seasonally. Nitrogen application response studies have previously been conducted on bell pepper. Seasonal $\mathrm{N}$ application of 135 to $252 \mathrm{~kg} \cdot \mathrm{ha}^{-1}$ to open-field peppers was found to increase flower number and fruit yield (Hartz et al., 1993). This $\mathrm{N}$ application rate resulted in yields of $\approx 50 \mathrm{t} \cdot \mathrm{ha}^{-1}$. Intensified models for pepper production commonly practice much higher application rates of nutrients including $\mathrm{N}$ than in the traditional open-field production systems. Nitrogen in these cases is applied continuously through drip irrigation systems (fertigation) at rates reaching 100 to $150 \mathrm{mg} \cdot \mathrm{L}^{-1} \mathrm{~N}$ and with seasonal application reaching 750 to $900 \mathrm{~kg} \cdot \mathrm{ha}^{-1} \mathrm{~N}$ (Bar-Tal et al., 2001; Jovicich et al., 2004; Schon et al., 1994).

Crop response to applied N and NUE are important criteria for evaluating $\mathrm{N}$ requirements for maximum economic yield (Fageria and Baligar, 2005). Recovery of applied $\mathrm{N}$ in crop plants is usually less than $50 \%$ (Fageria and Baligar, 2005; Glass, 2003). Hence, improving NUE is desirable to improve crop yields, reduce production costs, and maintain environmental quality (Fageria and Baligar, 2005). Use of plant species or genotypes efficient in absorption and use of $\mathrm{N}$ can facilitate $\mathrm{N}$ productivity and sustainable agricultural systems (Fageria and Baligar, 2005; Stefanelli et al., 2010). Genetic variability in NUE has been recognized for many years (Smith, 1934). In tomato, genotype variation was found to influence $\mathrm{N}$ use and assimilation (Ruiz and Romero, 1998). High NUE genotypes were characterized with higher accumulation of $\mathrm{NO}_{3}-\mathrm{N}$ in the leaves, high nitrate reductase activities, and high protein and organic N contents (Ruiz and Romero, 1998). Differences in $\mathrm{N}$ uptake and use have also been found among other crop species and cultivars including wheat, sorghum, corn, ryegrass, and soybean (Fageria and Baligar, 2005).

Global consumer interest regarding the quality of vegetable products has increased in recent years (Stefanelli et al., 2010). Product quality is a complex issue; in addition to visual characteristics, properties such as texture, the content of minerals and vitamins, 
and flavor and other organoleptic characteristics must be considered (Gruda, 2005). Recent research indicates that high rates of $\mathrm{N}$ application can have significant negative effects on fruit quality as well as on secondary plant metabolites and vitamin content of fruits and vegetables (Stefanelli et al., 2010). In root crops, high $\mathrm{N}$ can lead to reduced sensory quality. For example, sugar content can be reduced in potato and sugar beet if excessive $\mathrm{N}$ is applied late in the growing season (Mengel et al., 2001). In tomato, a decrease in $\mathrm{NO}_{3}-\mathrm{N}$ from 12 to $4 \mathrm{~mm}$ resulted in a slight yield reduction $(7.5 \%)$ and in improved fruit eating quality characterized by lower fruit acidity and higher soluble sugars (Bénard et al., 2009). Conversely, no significant effect on carotenoid content was found.

Sweet pepper is an excellent source of bioactive nutrients such as vitamin $\mathrm{C}$, provitamin A (carotenoids), phenolic compounds, and potassium, which define its nutritional quality and antioxidant capacity (Flores et al., 2004). Carotenoids, particularly lycopene, are powerful natural antioxidants recognized as beneficial for preventing a broad range of cancers and cardiovascular diseases (Byers and Perry, 1992). These antioxidant compounds are effective free radical scavengers and may be important for prevention of agerelated macular degeneration and cataracts (Howard et al., 2000).

The objective of this work was to evaluate strategies for increased horticultural NUE in greenhouse bell pepper by reducing $\mathrm{N}$ concentration in applied irrigation water or by using cultivars varying in vegetative growth vigor. We hypothesized that NUE could be improved and therefore environmental $\mathrm{N}$ contamination could be reduced without reductions in fruit yield or quality.

\section{Materials and Methods}

Experiment description and treatments. Four-week-old pepper plants were transplanted on 15 Aug. 2010 and grown until May 2011 in a greenhouse located at the Besor Experimental Station, Israel (lat. $31^{\circ} 16^{\prime} \mathrm{N}$, long. $34^{\circ} 23^{\prime} \mathrm{E}$ ). Each bed consisted of two plant rows with $40 \mathrm{~cm}$ between rows and $40 \mathrm{~cm}$ between plants within each row. The distance between beds was $180 \mathrm{~cm}$ (center to center) with $120-\mathrm{cm}$ paths between beds. The resulting density, 33,330 plants/ha, was in accordance with common local practice (S. Cohen, 2010, Negev Agricultural R\&D Center, Besor Experimental Station, personal communication). The two cultivars, 7180 (Makhteshim-Agan, Israel) and 7182 (Zeraim Gedera, Israel), both commonly grown in this region, were selected as a result of their different vegetative growth habits. The cultivar 7182 exhibits enhanced vigor under normal fertilization practices. Although the cultivars differ regarding their vegetative growth, the yield and size of fruits they produce are comparable.

Plants were irrigated using a drip system consisting of laterals adjacent to each pepper row. The total water volume irrigated during the growing season was $8750 \mathrm{~m}^{3} \cdot \mathrm{ha}^{-1}$ for all treatments. Irrigation was applied once a day, the volume based on reference evapotranspiration (ET) values adjusted to plant developmental stage. Seasonal reference ET measured outside of the greenhouse was $1270 \mathrm{~mm}$. The reference ET inside the structure was taken as 0.6 that of outside based on Tanny et al. (2003). Irrigation ranged from 2.5 to $4.0 \mathrm{~mm} \cdot \mathrm{d}^{-1}$. Water supplied for the experiment, originating from a regional desalinated plant, had electrical conductivity (EC) of $0.4 \mathrm{dS} \cdot \mathrm{m}^{-1}$. Pepper plants were irrigated for the first 2 weeks with irrigation solution containing $70 \mathrm{mg} \cdot \mathrm{L}^{-1}$ nitrogen, $30 \mathrm{mg} \cdot \mathrm{L}^{-1}$ phosphorus $(\mathrm{P})$, $60 \mathrm{mg} \cdot \mathrm{L}^{-1}$ potassium $(\mathrm{K}), 12 \mathrm{mg} \cdot \mathrm{L}^{-1}$ magnesium $(\mathrm{Mg}), 20 \mathrm{mg} \cdot \mathrm{L}^{-1}$ sulfur, $2 \mathrm{mg} \cdot \mathrm{L}^{-1}$ boron, $0.6 \mathrm{mg} \cdot \mathrm{L}^{-1}$ iron, $0.3 \mathrm{mg} \cdot \mathrm{L}^{-1}$ manganese, $0.2 \mathrm{mg} \cdot \mathrm{L}^{-1}$ zinc, $0.012 \mathrm{mg} \cdot \mathrm{L}^{-1}$ copper, $0.009 \mathrm{mg} \cdot \mathrm{L}^{-1}$ molybdenum, $44 \mathrm{mg} \cdot \mathrm{L}^{-1}$ chloride $(\mathrm{Cl})$, and $20 \mathrm{mg} \cdot \mathrm{L}^{-1}$ sodium (according to standard practice in Israel). Water application during this period was 435 to $450 \mathrm{~m}^{3} \cdot \mathrm{ha}^{-1}$ for all treatments. Differential $\mathrm{N}$ treatments were initiated 2 weeks after planting and continued throughout the growing season. Pepper plants were irrigated with four $\mathrm{N}$ concentrations in the irrigation solution: $9.2,56.2,102.3$, and $158.5 \mathrm{mg} \cdot \mathrm{L}^{-1} \mathrm{~N}$ (N9, N56, N102, and N158, respectively). All other micro- and macronutrients remained as described for the first 2 weeks, except $\mathrm{P}$ and $\mathrm{K}$ concentrations, which were changed to 20 and $100 \mathrm{mg} \cdot \mathrm{L}^{-1}$, respectively, in all treatments. These changes are according to local practice in which $\mathrm{P}$ concentration is reduced and $\mathrm{K}$ concentration is increased after transplanting and seedling establishment. The $\mathrm{N} 1$ treatment was achieved using $\mathrm{KH}_{2} \mathrm{PO}_{4}, \mathrm{~K}_{2} \mathrm{SO}_{4}$, and $\mathrm{MgNO}_{3}$. The N56, $\mathrm{N} 102$, and N158 treatments were based on commercial liquid fertilizers $\left(\mathrm{N}-\mathrm{P}_{2} \mathrm{O}_{5}-\mathrm{K}_{2} \mathrm{O}\right)$ : $3.3-3-9,4-2-6$, and 6-2-6, respectively (Fertilizers \& Chemicals LTD, Haifa, Israel). Chemical properties and the applied nutrient composition of irrigation solutions are specified in Table 1. Total $\mathrm{N}$ applied through the different treatments was $108,498,880$, and $1343 \mathrm{~kg} \cdot \mathrm{ha}^{-1} \mathrm{~N}$, respectively, calculated according to irrigation water volume multiplied by average solution $\mathrm{N}$ concentration throughout the growing season. Common application rates in bell pepper grown under passive protective environments in this region or when grown in soilless culture or low-fertility soils reach 750 to $900 \mathrm{~kg} \cdot \mathrm{ha}^{-1} \mathrm{~N}$ (Bar-Tal et al., 2001; Jovicich et al., 2004; Schon et al., 1994). The ratio of $\mathrm{NO}_{3}-\mathrm{N}: \mathrm{NH}_{4}-\mathrm{N}$ (ammonium) was in the range of 2 to 9 , which, according to Bar-Tal et al. (2001), was not expected to cause inhibition of $\mathrm{N}$ uptake by pepper plants.

The experiment was arranged in a split plot design with four replicates; each block consisted of four beds, each bed was randomly irrigated with a specific $\mathrm{N}$ concentration (main plots); cultivars (subplots) were randomly arranged along the bed. Each plot was $9 \mathrm{~m}$ long and contained 42 plants grown in two rows. A non-permeable plastic barrier was buried to $50-\mathrm{cm}$ depth between adjacent beds to prevent contamination between $\mathrm{N}$ treatments.

Irrigation solution, soil, and plant analysis. Irrigation solution was collected weekly for determination of $\mathrm{pH}, \mathrm{EC}$, and mineral concentrations. Phosphorus, $\mathrm{NO}_{3}-\mathrm{N}$, and $\mathrm{NH}_{4}-\mathrm{N}$ were determined using an Autoanalyzer (Lachat Instruments, Milwaukee, WI). Potassium and $\mathrm{Mg}$ were determined by atomic absorption spectrophotometer (AAnalyst 200; PerkinElmer). Soil (0 to $20 \mathrm{~cm}$ and 20 to $40 \mathrm{~cm}$ depth) was sampled at three locations within the experimental plot before treatment initiation and analyzed for some physical and chemical properties. At the end of the experiment, soil samples were collected under the dripline in each replicate plot from three depths, 0 to 30,30 to 60 , and 60 to $90 \mathrm{~cm}$, to determine $\mathrm{N}$ content. Soil samples were oven-dried $\left(105^{\circ} \mathrm{C}\right)$ and ground to less than 2 $\mathrm{mm}$ size. $\mathrm{EC}, \mathrm{pH}, \mathrm{NO}_{3}-\mathrm{N}, \mathrm{K}$, and $\mathrm{Cl}$ were determined in a filtered solution of saturated paste extract. Calcium carbonate $\left(\mathrm{CaCO}_{3}\right)$ was analyzed by calcimeter (P1.85; Eijkelkamp). $\mathrm{P}$ was extracted following the Olsen bicarbonate extractable P method (Pierzynski, 2000). Chloride was determined with a chloride analyzer (Model 926; Sherwood). Average values and standard deviations of the soil properties are given in Table 2. Leaf petioles (20 to 25) from each treatment were collected at 110, 139, 153, 167, 194, 208, 222 , and $250 \mathrm{~d}$ after planting (DAP). Leaf petioles were cut into small pieces and kept at $5{ }^{\circ} \mathrm{C}$ for $30 \mathrm{~d}$ before analysis. A total of $0.5 \mathrm{~g}$ fresh material was homogenized in $10 \mathrm{~mL}$ deionized water, extracted, and filtered. $\mathrm{NO}_{3}-\mathrm{N}$ concentration in the resulting extract was determined after filtering using RQFlex ${ }^{\circledR}$ Analyzer (RQFlex2; Merck, Germany). Total N was determined in diagnostic leaves (the youngest fully expanded leaf, usually leaf number 4 to 5 from the apical meristem) and plant organs. Ten diagnostic leaves were collected from each plot. The leaves were rinsed with deionized water, dried at $70{ }^{\circ} \mathrm{C}$, and ground. Nitrogen was determined as described previously after digestion with sulfuric acid and hydrogen peroxide (Snell and Snell, 1949).

Just after the last harvest (257 DAP), four plants from each plot were manually excavated with a shovel, each in an area $20 \mathrm{~cm} \times$ $20 \mathrm{~cm}$, with the plant in the center of the square, to a depth of $30 \mathrm{~cm}$ according to

Table 1. Nutrient composition in irrigation water. ${ }^{z}$

\begin{tabular}{lccrrr}
\hline Treatment & $\mathrm{pH}$ & $\begin{array}{c}\text { Electrical conductivity } \\
\left(\mathrm{dS} \cdot \mathrm{m}^{-1}\right)\end{array}$ & $\begin{array}{c}\mathrm{NO}_{3}-\mathrm{N} \\
\left(\mathrm{mg} \cdot \mathrm{L}^{-1}\right)\end{array}$ & $\begin{array}{r}\mathrm{NH}_{4}-\mathrm{N} \\
\left(\mathrm{mg}^{-1} \mathrm{~L}^{-1}\right)\end{array}$ & $\begin{array}{r}\text { Total nitrogen } \\
\left(\mathrm{mg} \cdot \mathrm{L}^{-1}\right)\end{array}$ \\
\hline N9 & $6.7(0.1)$ & $0.79(0.02)$ & $8.3(0.3)$ & $0.9(0.4)$ & $9.2(0.4)$ \\
N56 & $6.5(0.1)$ & $0.83(0.04)$ & $50.2(3.7)$ & $6.0(0.9)$ & $56.2(4.3)$ \\
N102 & $6.3(0.2)$ & $1.06(0.02)$ & $75.4(2.1)$ & $26.9(0.8)$ & $102.3(2.1)$ \\
N158 & $6.2(0.2)$ & $1.35(0.04)$ & $107.8(3.8)$ & $50.7(1.5)$ & $158.5(4.7)$ \\
\hline
\end{tabular}

${ }^{\mathrm{z}}$ Values represent average and SEM. 
Table 2. Soil physical and chemical properties before experimental treatments. ${ }^{\mathrm{z}}$

\begin{tabular}{|c|c|c|c|c|c|c|c|c|c|c|c|c|c|}
\hline \multirow[b]{2}{*}{$\begin{array}{c}\text { Depth } \\
(\mathrm{cm})\end{array}$} & \multicolumn{5}{|c|}{ Physical properties } & \multicolumn{8}{|c|}{ Chemical properties } \\
\hline & $\begin{array}{l}\text { Sand } \\
(\%)\end{array}$ & $\begin{array}{l}\text { Silt } \\
(\%)\end{array}$ & $\begin{array}{l}\text { Clay } \\
(\%)\end{array}$ & SP & $\begin{array}{l}\text { Bulk density } \\
\left(\mathrm{g} \cdot \mathrm{mL}^{-1}\right)\end{array}$ & $\begin{array}{c}\mathrm{EC} \\
\left(\mathrm{dS} \cdot \mathrm{m}^{-1}\right)\end{array}$ & $\mathrm{pH}$ & $\begin{array}{c}\mathrm{NO}_{3}-\mathrm{N} \\
\left(\mathrm{mg} \cdot \mathrm{kg}^{-1}\right)\end{array}$ & $\begin{array}{c}\mathrm{P} \\
\left(\mathrm{mg} \cdot \mathrm{kg}^{-1}\right)\end{array}$ & $\begin{array}{c}\mathrm{K} \\
\left(\mathrm{meq} \cdot \mathrm{L}^{-1}\right)\end{array}$ & $\begin{array}{c}\mathrm{Cl} \\
\left(\mathrm{meq} \cdot \mathrm{L}^{-1}\right)\end{array}$ & $\begin{array}{c}\mathrm{CaCO}_{3} \\
(\%)\end{array}$ & $\begin{array}{l}\text { OM } \\
(\%)\end{array}$ \\
\hline $0-20$ & $92.9(0.4)$ & $1.3(0.1)$ & $5.8(0.4)$ & $27.2(1.2)$ & $1.81(0.12)$ & $1.1(0.10)$ & $7.9(0.4)$ & $8.7(0.4)$ & $76.5(3.8)$ & $0.70(0.03)$ & $1.89(0.09)$ & $4.1(0.8)$ & $1.41(0.13)$ \\
\hline $20-40$ & $90.3(1.2)$ & $2.4(0.4)$ & $7.3(0.9)$ & $28.5(0.1)$ & $2.10(0.19)$ & $0.8(0.04)$ & $7.7(0.4)$ & $5.3(0.3)$ & $92.5(4.6)$ & $0.59(0.03)$ & $1.21(0.06)$ & $5.9(0.6)$ & $1.08(0.10)$ \\
\hline
\end{tabular}

zValues represent average and SEM.

$\mathrm{SP}=$ saturation percentage; $\mathrm{EC}=$ electrical conductivity of soil-saturated paste extract; $\mathrm{P}=$ Olsen bicarbonate extractable phosphorus; $\mathrm{K}=$ potassium; $\mathrm{Cl}=$ chloride; $\mathrm{OM}=$ soil organic matter content.

Qawasmi et al. (1999). Three of the plants were analyzed for height and fresh weight. The remaining plants were partitioned into roots, shoots (stems and leaves), and fruits. Samples were rinsed with deionized water, dried at $70{ }^{\circ} \mathrm{C}$, weighed, and ground. Nitrogen concentration of each plant organ was determined as described previously for diagnostic leaves.

Fruit physical and chemical properties. Ripe fruits were harvested weekly; fruit weight, fruit number, and percent of marketable fruits were determined for each replicate plot. Fruit physical properties and chemical fruit quality parameters were analyzed three times during the growing season, twice during the maximum yield accumulation period (168 and 207 DAP), and just before the last harvest (250 DAP). Fruit quality and analysis of fruit nutritional value were conducted on five fully mature, red ripe, export-grade pepper fruits without any biotic or physiological disorders such as cracking or blossom end rot. Pulp thickness was measured on three points of the equatorial area in half of each fruit. The other half was homogenized in a food processor and extract was frozen at $-20{ }^{\circ} \mathrm{C}$ until further analysis. For each replicate, five fruit extracts were combined and centrifuged for measurements of $\mathrm{pH}$, total soluble solids (TSS) content, acidity, $\mathrm{NO}_{3}-\mathrm{N}$ content, and glucose. The TSS in the juice was determined by an Atago N1 (Japan) refractometer and expressed as ${ }^{\circ}$ Brix at 20 ${ }^{\circ} \mathrm{C}$. Acidity was determined by potentiometric titration with $0.1 \mathrm{M} \mathrm{NaOH}$, to $\mathrm{pH} 8.1$, using $10 \mathrm{~mL}$ of juice. Results are expressed as the concentration of citric acid in the pepper juice. To evaluate possible $\mathrm{NO}_{3}-\mathrm{N}$ accumulation in the harvested fruits during the growth season, $\mathrm{NO}_{3}-\mathrm{N}$ concentrations were determined in juice of marketable fruits from each plot at three different times as mentioned previously. Glucose concentration was determined in pepper juice after dilution in deionized water (1:20 v:v) using Glucometer (Optimum Xceed; Abbott).

Lycopene and $\beta$-carotene determination. A 1-mL pepper juice sample was homogenized with $16 \mathrm{~mL}$ of acetone/hexane $(4 / 6 \mathrm{v} /$ $\mathrm{v})$, and the supernatant was collected for determination of pigment content. $\beta$-carotene and lycopene were determined in the supernatant by measurement of the optical density at $663,645,505$, and $453 \mathrm{~nm}$ using a spectrophotometer (Infinity 200; TECAN, Switzerland). From these values, $\beta$-carotene and lycopene concentrations were quantified as proposed by Nagata and Yamashita (1992):

$$
\begin{aligned}
& \beta \text { - carotene mg. }(100 \mathrm{~mL})^{-1} \\
& =0.216 A_{663}-1.220 A_{645} \\
& \quad-0.304 A_{505}+0.452 A_{453} \\
& \text { Lycopene } \mathrm{mg} \cdot(100 \mathrm{~mL})^{-1} \\
& =-0.0458 A_{663}+0.204 A_{645}+0.372 A_{505} \\
& \quad-0.0806 A_{453}
\end{aligned}
$$

where $A_{663}, A_{645}, A_{505}$, and $A_{453}$ are the absorbance measured at $663,645,505$, and $453 \mathrm{~nm}$, respectively. These equations allow the simultaneous determination of $\beta$-carotene and lycopene in the presence of chlorophylls.

Antioxidant activity assays. To cover diverse antioxidant bioactive groups, subsamples of pepper juice used for pigment content were analyzed for antioxidant capacity using the following methods: oxygen radical absorption capacity according to Prior et al. (2003); ferric reducing antioxidant capacity according to Benzie and Strain (1996); and cyclic voltammetry and differential pulse voltammetry according to Butera et al. (2002) and Raveh et al. (2009).

Nitrogen use efficiency. Nitrogen use efficiency can be calculated in many ways (Fageria and Baligar, 2005; Van Eerd, 2007). We define NUE in the following ways:

1. Environmental NUE (ENUE); $N_{u p} / N_{a p p}$, where $N_{u p}$ is seasonal $\mathrm{N}$ taken up by plants $\left(\mathrm{kg} \cdot \mathrm{ha}^{-1}\right), N_{a p p}$ is seasonal applied $\mathrm{N}\left(\mathrm{kg} \cdot \mathrm{ha}^{-1}\right)$.

2. Agronomic NUE (ANUE); $Y_{f} / N_{a p p}$, where $Y_{f}$ is marketable fruit yield $\left(\mathrm{Mg} \cdot \mathrm{ha}^{-1}\right), N_{a p p}$ is seasonal applied $\mathrm{N}$ $\left(\mathrm{kg} \cdot \mathrm{ha}^{-1}\right)$.

3. Biomass NUE (BNUE); $Y_{b m} / N_{a p p}$, where $Y_{b m}$ is total dry biomass production (kg dry wt/ha), $N_{a p p}$ is seasonal applied $\mathrm{N}\left(\mathrm{kg} \cdot \mathrm{ha}^{-1}\right)$.

4. Plant production NUE (PPNUE); $Y_{f}$ $N_{u p}$, where $Y_{f}$ is marketable fruit yield $\left(\mathrm{Mg} \cdot \mathrm{ha}^{-1}\right), N_{u p}$ is seasonal $\mathrm{N}$ taken up by plants $\left(\mathrm{kg} \cdot \mathrm{ha}^{-1}\right)$.

Nitrogen loading to the environment. Environmental $\mathrm{N}$ load was calculated according to the following equation (Segal et al., 2011):

$$
\begin{gathered}
\mathrm{NO}_{3}^{\text {irrigation }}+\mathrm{NO}_{3}^{\text {nitrification }}-\mathrm{NO}_{3}^{\text {plant }} \\
-\Delta \mathrm{NO}_{3}^{\text {soil }}=\mathrm{NO}_{3}^{\text {drainage }}
\end{gathered}
$$

where $\mathrm{NO}_{3}{ }^{\text {irrigation }}$ indicates $\mathrm{N}$ applied by irrigation; $\mathrm{NO}_{3}{ }^{\text {nitrification }}$ is addition of $\mathrm{N}$ by nitrification; $\mathrm{NO}_{3}{ }^{\text {plant }}$ is $\mathrm{N}$ removed by plants throughout the season; and $\Delta \mathrm{NO}_{3}{ }^{\text {soil }}$ is the seasonal change in $\mathrm{N}$ found in the soil. Nitrogen concentration in the soil profile before transplanting and before last harvest was determined.

The $\mathrm{N}$ balance was calculated in $\mathrm{kg} \cdot \mathrm{ha}^{-1}$ units for the upper $30 \mathrm{~cm}$ of the soil profile, where roots were visibly concentrated and assumed to be most active regarding water and nutrient uptake under the drip-irrigated conditions. Soil N storage capacity was calculated based on measured soluble $\mathrm{N}$ concentrations in the soil paste and measured saturation percentage from the end of the growing season (May), estimated soil bulk density $\left(1810 \mathrm{~kg} \cdot \mathrm{m}^{-3}\right)$, and active root zone volume $\left(1500 \mathrm{~m}^{3} \cdot \mathrm{ha}^{-1}\right.$, based on a wet strip of $\approx 0.75 \mathrm{~m}$ width $\times 0.3 \mathrm{~m}$ depth below the dripline). The estimation of $\mathrm{N}$ plant uptake was calculated as combined removal by the fruits, canopy, and roots. Nitrogen removal by the fruits was based on measured concentration in fruits and fruit biomass. Nitrogen removal by the canopy was calculated from estimated dry weight of leaf and stem biomass and measured concentrations in leaves and stems. Nitrogen removal by plant roots was based on measured concentration in roots and root biomass. Nitrification was assumed to be rapid as typically found in irrigated soils (Strong et al., 1999).

Statistical analysis. Plant growth data, yield, yield component, fruit quality, $\mathrm{N}$ concentration, environmental NUE, agronomic NUE, biomass NUE, and plant production NUE were analyzed by two-way analysis of variance (taking into consideration the split plot design) with JMP 10.0 software (SAS Institute Inc., Cary, NC). Default significance levels were set at $\alpha=0.05$.

\section{Results}

Nitrogen in the plant. Nitrogen uptake and accumulation, as characterized by $\mathrm{NO}_{3}-\mathrm{N}$ in leaf petioles ( $\mathrm{N}$ uptake) and by $\mathrm{N}$ concentration in diagnostic leaves ( $\mathrm{N}$ accumulation) of pepper plants, increased significantly as a function of increasing irrigation $\mathrm{N}$ concentration (Table 3). However, no difference in $\mathrm{N}$ concentration was found between the two highest $\mathrm{N}$ treatments. This indicates that, under our experimental conditions, $\mathrm{N}$ concentration of $102.3 \mathrm{mg} \cdot \mathrm{L}^{-1}$ (N102) was sufficient for maximum $\mathrm{N}$ uptake. Although the cultivars tested in our experiment differed in their vegetative growth vigor (Table 4), there was no significant difference in $\mathrm{N}$ concentration between them (Table 3). Although the vegetative growth response of both cultivars to $\mathrm{N}$ was linearly correlated, the response in fruit yield was curvilinear with optimum found for 
the median concentrations and a decrease at the highest one.

Nitrogen treatments had an impact on total $\mathrm{N}$ content and on its allocation among plant organs (Table 5). In general, in each plant organ, $\mathrm{N}$ content increased with increasing irrigation $\mathrm{N}$ concentration. The low $\mathrm{N}$ concentration led to significantly reduced $\mathrm{N}$ content compared with the two highest $\mathrm{N}$ concentrations in all organs except roots. Total plant $\mathrm{N}$ content increased by $49 \%$, $73 \%$, and $84 \%$ with increasing $\mathrm{N}$ concentration from 9.2 to $56.2,102.3$, and 158.5 $\mathrm{mg} \cdot \mathrm{L}^{-1}$, respectively. No significant differences in $\mathrm{N}$ uptake or distribution were found between the cultivars with the exception of $\mathrm{N}$ found in roots. The vigorous cultivar (7182) accumulated significantly less $\mathrm{N}$ in the roots $\left(16 \mathrm{~kg} \cdot \mathrm{ha}^{-1}\right)$ as compared with the $29 \mathrm{~kg} \cdot \mathrm{ha}^{-1}$ $\mathrm{N}$ in cultivar 7180 (Table 5). Increasing $\mathrm{N}$ concentration in the irrigation water modified $\mathrm{N}$ accumulation in the different plant organs (Table 5). At low $\mathrm{N}$ concentration, fruits accumulated $44 \%$ of the $\mathrm{N}$ taken up by the plant, whereas only $32 \%$ of total $\mathrm{N}$ was found in fruits for the highest $\mathrm{N}$ concentration. The opposite trend was found for leaves and stems. Conversely, $\mathrm{N}$ content in roots was unaffected by $\mathrm{N}$ concentration.

Nitrogen effect on plant height, weight, fruit number, and yield. Pepper plants grown under low $\mathrm{N}$ concentration treatment (N9) were significantly shorter and accumulated less fresh biomass at the end of the growing

Table 3. Average nitrogen $(\mathrm{N})$ concentration in petiole extracts and diagnostic leaves during the growing season. ${ }^{\mathrm{z}}$

\begin{tabular}{|c|c|c|c|}
\hline \multicolumn{2}{|c|}{ Treatment } & \multicolumn{2}{|c|}{ Nitrogen level } \\
\hline Nitrogen & Cultivar & Petiole $\mathrm{NO}_{3}-\mathrm{N}\left(\mathrm{mg} \cdot \mathrm{L}^{-1}\right)$ & Diagnostic leaves N (\% of dry wt) \\
\hline$\overline{\mathrm{N} 9}$ & 7180 & 1917 & 3.83 \\
\hline N56 & & 4600 & 5.27 \\
\hline N102 & & 8213 & 5.49 \\
\hline N158 & & 8243 & 5.52 \\
\hline N9 & 7182 & 2683 & 4.04 \\
\hline N56 & & 3484 & 4.94 \\
\hline N102 & & 8224 & 5.44 \\
\hline N158 & & 8498 & 5.91 \\
\hline \multicolumn{4}{|l|}{ Nitrogen } \\
\hline N9 & & $2300 \mathrm{C}$ & $3.94 \mathrm{C}$ \\
\hline N56 & & 4042 B & $5.11 \mathrm{~B}$ \\
\hline N102 & & $8218 \mathrm{~A}$ & $5.47 \mathrm{AB}$ \\
\hline N158 & & $8370 \mathrm{~A}$ & $5.72 \mathrm{~A}$ \\
\hline \multicolumn{4}{|l|}{ Cultivar } \\
\hline 7180 & & $5743 \mathrm{~A}$ & $5.03 \mathrm{~A}$ \\
\hline 7182 & & $5722 \mathrm{~A}$ & $5.09 \mathrm{~A}$ \\
\hline Nitrogen & & NS & NS \\
\hline \multicolumn{4}{|c|}{$\begin{array}{l}\text { zPepper plants of two cultivars were irrigated with four levels of } \mathrm{N} \text { in the irrigation solution, } 9.2,56.2 \text {, } \\
102.3 \text {, and } 158.5 \mathrm{mg} \cdot \mathrm{L}^{-1} \mathrm{~N}(\mathrm{~N} 9, \mathrm{~N} 56, \mathrm{~N} 102 \text {, and N158, respectively). Treatments accompanied with the } \\
\text { same letter are not significantly different according to Tukey's honestly significant difference two-way } \\
\text { analysis of variance with JMP } 10.0 \text { software (SAS Institute Inc., Cary, NC). Default significance levels } \\
\text { were set at } \alpha=0.05 \text {. }\end{array}$} \\
\hline
\end{tabular}

Table 4. Nitrogen $(\mathrm{N})$ effect on plant height, weight, fruit number, and yield at the end of the growing season. $^{\mathrm{z}}$

\begin{tabular}{|c|c|c|c|c|c|}
\hline \multicolumn{2}{|c|}{ Treatment } & \multirow[b]{2}{*}{$\mathrm{Ht}$ (cm/plant) } & \multirow{2}{*}{$\begin{array}{l}\text { Shoot fresh wt } \\
\text { (g/plant) }\end{array}$} & \multirow{2}{*}{$\begin{array}{l}\text { Fruit number } \\
\text { (thousand/ha) }\end{array}$} & \multirow{2}{*}{$\begin{array}{c}\text { Fruit yield } \\
\left(\mathrm{Mg} \cdot \mathrm{ha}^{-1}\right)\end{array}$} \\
\hline Nitrogen & Cultivar & & & & \\
\hline N9 & 7180 & 194.0 & 1361.4 & 346 & 63.9 \\
\hline N56 & & 224.8 & 2127.3 & 441 & 83.9 \\
\hline N102 & & 216.8 & 1981.1 & 410 & 77.1 \\
\hline N158 & & 222.4 & 2681.9 & 382 & 73.1 \\
\hline N9 & 7182 & 218.9 & 1667.8 & 387 & 72.5 \\
\hline N56 & & 255.4 & 2648.1 & 516 & 99.8 \\
\hline N102 & & 256.4 & 3158.6 & 467 & 89.9 \\
\hline N158 & & 259.2 & 2834.3 & 436 & 83.2 \\
\hline \multicolumn{6}{|l|}{ Nitrogen } \\
\hline N9 & & $206.5 \mathrm{~B}$ & $1514.6 \mathrm{~B}$ & $367 \mathrm{C}$ & $68.2 \mathrm{C}$ \\
\hline N56 & & $240.1 \mathrm{~A}$ & $2387.7 \mathrm{AB}$ & $478 \mathrm{~A}$ & $91.8 \mathrm{~A}$ \\
\hline N102 & & $236.6 \mathrm{~A}$ & $2569.8 \mathrm{AB}$ & $438 \mathrm{AB}$ & $83.5 \mathrm{AB}$ \\
\hline N158 & & $240.8 \mathrm{~A}$ & $2758.1 \mathrm{~A}$ & $409 \mathrm{BC}$ & $78.2 \mathrm{~B}$ \\
\hline \multicolumn{6}{|l|}{ Cultivar } \\
\hline 7180 & & $214.5 \mathrm{~B}$ & $2037.9 \mathrm{~B}$ & $395 \mathrm{~B}$ & $74.5 \mathrm{~B}$ \\
\hline 7182 & & $247.5 \mathrm{~A}$ & $2577.2 \mathrm{~A}$ & $451 \mathrm{~A}$ & $86.3 \mathrm{~A}$ \\
\hline Nitrogen $>$ & var & NS & NS & NS & NS \\
\hline
\end{tabular}

zPepper plants of two cultivars were irrigated with four levels of $\mathrm{N}$ in the irrigation solution, 9.2, 56.2 102.3 , and $158.5 \mathrm{mg} \cdot \mathrm{L}^{-1} \mathrm{~N}$ (N9, N56, N102, and N158, respectively). Treatments accompanied with the same letter are not significantly different according to Tukey's honestly significant difference two-way analysis of variance with JMP 10.0 software (SAS Institute Inc., Cary, NC). Height and fresh weight data are average of 12 plants from each treatment. Default significance levels were set at $\alpha=0.05$.

NS $=$ nonsignificant. season compared with the other $\mathrm{N}$ treatments (Table 4). No differences were found for these two growth parameters between the other N concentrations. Detailed information on plant organ dry weight and content is presented in Supplemental Table S1 (available online). The more vigorous ' 7182 ' plants were taller and produced more biomass compared with 7180 cultivar plants. In contrast with the vegetative growth parameters, total yields were more significantly affected by $\mathrm{N}$ treatment level. The highest yields for both cultivars were found when pepper plants were irrigated with $56.2 \mathrm{mg} \cdot \mathrm{L}^{-1} \mathrm{~N}$ throughout the season (Table 4). A significant yield reduction was found for both suboptimal $\mathrm{N}$ concentration (N9) and for the high concentration (N158). The effect of $\mathrm{N}$ concentration in the irrigation solution on fruit number was correlated with its effect on fruit yield. The vigorous cultivar (7182) produced more fruits and had higher yields at the end of the growing season compared with cultivar 7180 .

Weekly harvest data were used to evaluate the effects of $\mathrm{N}$ application level on yield parameters during the growing season. In general, fruit size was not significantly affected by $\mathrm{N}$ treatments. In the middle of the growing season (141 to 207 DAP), a period of high-quality export-grade production, fruit number was significantly affected by $\mathrm{N}$ concentration in the irrigation water (Fig. 1; middle panel and Table 6). The N56 treatment accumulated the greatest number of fruits during the growing season (Fig. 1; Table 6). For example, at 207 DAP, plants receiving the N56 treatment accumulated between 40 to 46 and 65 to 86 thousand more fruits compared with the other $\mathrm{N}$ treatments in 7180 and 7180 cultivars, respectively (Table 6). The low $\mathrm{N}$ treatment (N9) accumulated a similar number of fruits as that found in the N56 treatment at the beginning of the growing season (until 141 DAP; Table 6). However, the N9 treatment accumulated a lower total seasonal number of fruits (Table 4; Fig. 1) compared with all the other $\mathrm{N}$ treatments. The increases in fruit number were not accompanied by reduction in fruit size (Fig. 1; Table 6). Irrigation with high $\mathrm{N}$ concentrations $\mathrm{N} 102$ and $\mathrm{N} 158$ resulted in lower fruit production (Table 6). The two cultivars responded differently to the $\mathrm{N}$ treatments. Both cultivars produced a similar number of ripe fruits until 207 DAP (Fig. 1; Table 6). However, the vigorous cultivar 7182 produced significantly more fruits compared with the cultivar 7180 from 207 DAP by the end of the season (Fig. 1; Tables 4 and $6)$. This increase in fruit number was accompanied by a significant reduction in fruit size (Table 6).

Nitrogen influences on fruit quality. Fruit quality parameters were similar for the three sampling dates. The first two sampling dates represent the predominant period of highquality pepper exports from the growing region and therefore we have chosen to focus on these results. Nitrogen concentration in the irrigation water had no significant effects on any of the physical fruit quality parameters 
Table 5. Nitrogen $(\mathrm{N})$ content in different plant organs and $\mathrm{N}$ use efficiencies (NUE) as affected by $\mathrm{N}$ concentration in irrigation water. ${ }^{\mathrm{z}}$

\begin{tabular}{|c|c|c|c|c|c|c|c|c|c|c|}
\hline \multicolumn{2}{|c|}{ Treatment } & \multicolumn{5}{|c|}{ Plant organ $\left(\mathrm{kg} \cdot \mathrm{ha}^{-1} \mathrm{~N}\right)$} & \multicolumn{4}{|c|}{ Nitrogen use efficiency } \\
\hline Nitrogen & Cultivar & Stem & Leaf & Root & Fruit & Total & $\overline{\text { ENUE \% }}$ & BNUE $\mathrm{kg} \cdot \mathrm{kg}^{-1}$ & ANUE $\mathrm{kg} \cdot \mathrm{kg}^{-1}$ & PPNUE $\mathrm{kg} \cdot \mathrm{kg}^{-1}$ \\
\hline N56 & & 121.5 & 126.6 & 25.9 & 152.6 & 426.7 & 96.3 & 45.9 & 189.4 & 201.1 \\
\hline N158 & & 162.1 & 136.1 & 39.0 & 167.4 & 504.6 & 39.8 & 15.4 & 57.7 & 144.5 \\
\hline N9 & 7182 & 60.7 & 71.7 & 12.9 & 125.6 & 270.9 & 246.3 & 139.9 & 659.4 & 281.2 \\
\hline N56 & & 89.5 & 104.7 & 16.2 & 148.6 & 359.0 & 81.1 & 46.0 & 225.2 & 281.5 \\
\hline \multicolumn{11}{|l|}{ Nitrogen } \\
\hline N9 & & $62.7 \mathrm{~B}$ & $67.5 \mathrm{~B}$ & $17.5 \mathrm{~A}$ & $116.2 \mathrm{~B}$ & $264.0 \mathrm{~B}$ & $240.0 \mathrm{~A}$ & $139.3 \mathrm{~A}$ & $621.3 \mathrm{~A}$ & $269.3 \mathrm{~A}$ \\
\hline N56 & & $105.5 \mathrm{AB}$ & $115.7 \mathrm{AB}$ & $21.1 \mathrm{~A}$ & $150.6 \mathrm{~A}$ & $392.8 \mathrm{~A}$ & $88.7 \mathrm{~B}$ & $45.9 \mathrm{~B}$ & $205.0 \mathrm{~B}$ & $241.3 \mathrm{AB}$ \\
\hline N102 & & $138.1 \mathrm{~A}$ & $142.0 \mathrm{~A}$ & $21.8 \mathrm{~A}$ & $155.6 \mathrm{~A}$ & $457.5 \mathrm{~A}$ & $53.4 \mathrm{~B}$ & $22.8 \mathrm{BC}$ & $97.5 \mathrm{C}$ & $188.1 \mathrm{AB}$ \\
\hline N158 & & $153.3 \mathrm{~A}$ & $145.3 \mathrm{~A}$ & $30.1 \mathrm{~A}$ & $158.1 \mathrm{~A}$ & $486.9 \mathrm{~A}$ & $38.4 \mathrm{~B}$ & $15.5 \mathrm{C}$ & $61.3 \mathrm{C}$ & $166.4 \mathrm{~B}$ \\
\hline \multicolumn{11}{|l|}{ Cultivar } \\
\hline
\end{tabular}

${ }^{2}$ Environmental NUE (ENUE) $=$ ratio between the seasonal $\mathrm{N}$ taken up by plants and the supplied $\mathrm{N}$. Dry biomass NUE $(\mathrm{BNUE})=$ ratio between total dry biomass production and the supplied N. Agronomic NUE $($ ANUE) $=$ ratio between the marketable fruit yield and the supplied N. Plant production NUE $($ PPNUE) $=$ ratio between the marketable fruit yield and the seasonal $\mathrm{N}$ taken up by plants. Pepper plants were irrigated with four levels of $\mathrm{N}$ in the irrigation solution, 9.2, 56.2, 102.3 , and $158.5 \cdot \mathrm{mg} \cdot \mathrm{L}^{-1} \mathrm{~N}$ (N9, N56, N102, and N158, respectively). Treatments accompanied with the same letter are not significantly different according to Tukey's honestly significant difference two-way analysis of variance with JMP 10.0 software (SAS Institute Inc., Cary, NC). Default significance levels were set at $\alpha=0.05$.

$\mathrm{NS}=$ nonsignificant.

studied: fruit weight, fruit seed weight, or pericarp width (Table 7). Similarly, fruit chemical quality, including TSS, glucose content, $\mathrm{pH}$, and acidity, were unaffected by $\mathrm{N}$ treatments (Table 7). The $\mathrm{N}$ treatments were manifested similarly at both harvest time 168 and 207 DAP. Slight differences between the two harvest times were the result of the increase in average fruit size (Table 7; Fig. 1; Supplemental Table S2, available online) found at 207 DAP caused by a longer development period. The latter harvest was characterized by lower average daily temperatures, which affected the fruit maturation period. No significant differences between the two cultivars were found in any of the fruit quality parameters studied at the different harvest times (Table 7; Supplemental Table S2, available online).

Nitrogen influences on fruit nutritional value. Similar to fruit physical and chemical quality parameters, no significant effects on pepper nutritional values as a result of either $\mathrm{N}$ treatment or cultivar were found. Total antioxidant capacity was unaffected by $\mathrm{N}$ concentration in the irrigation water (Table 8). Minor differences in total antioxidant capacity were found between the two harvesting dates. Fruits harvested at 207 DAP had higher capacity as compared with fruits harvested at 168 DAP (Supplemental Table S3, available online). These differences might be related to dissimilarities in environmental conditions during fruit development and maturation. Nitrogen concentrations did not have significant effects on either $\beta$-carotene or lycopene accumulation in the fruits at either of the harvesting dates (Table 8; Supplemental Table S3, available online).

Nitrogen in the soil. The concentration of $\mathrm{NH}_{4}-\mathrm{N}$ in the soil solution was very low both before planting and at the end of the experiment (data not shown), and the sandy soil used in this work is characterized by a very low cation exchange capacity. Therefore, the $\mathrm{NO}_{3}-\mathrm{N}$ could be considered as the total inorganic $\mathrm{N}$ for calculations of mass balance. Nitrogen concentration in the irrigation water significantly affected distribution of inorganic $\mathrm{N}$ in the soil profile (Fig. 2). In the two high N concentrations (N102 and N158 treatments), considerable concentrations of $\mathrm{N}$ were found at all soil depths $(0$ to $30 \mathrm{~cm}, 30$ to $60 \mathrm{~cm}$, and 60 to $90 \mathrm{~cm}$ ). On the other hand, at low $\mathrm{N}$ concentration treatments (N9 and N56), $\mathrm{N}$ was barely detected throughout the soil profile.

Nitrogen use efficiency. All $\mathrm{N}$ use productivity/efficiency calculations were significantly affected by $\mathrm{N}$ concentration in irrigation water (Table 5). The low $\mathrm{N}$ treatment (N9) had the highest efficiency with an environmental NUE value of $240 \%$ meaning that $\mathrm{N}$ plant uptake was much higher than $\mathrm{N}$ applied through fertilizer. This is probably the result of mineralization of organic $\mathrm{N}$ and/ or the result of the presence of residual $\mathrm{N}$ (Table 2). However, this treatment also had significantly lower yields compared with the other $\mathrm{N}$ treatments (Table 4; Fig. 1). The second highest environmental NUE was calculated for the N56 treatment. In this N concentration, pepper plants took up $89 \%$ of the applied N. At high $\mathrm{N}$ concentrations (N102 and N158), plant uptake represented only $53 \%$ and $38 \%$ of applied N, respectively (Table 5). A similar effect was found when NUE was calculated for dry matter accumulation (biomass NUE, Table 5). Cultivar differences were found for agronomic NUE and plant production NUE, which are both related to fruit production (Table 5). The vigorous cultivar 7182 produced $40 \mathrm{~kg}$ more fruit for each kilogram $\mathrm{N}$ applied or taken up by the plants as compared with cultivar 7180 (Table 5).

Environmental implications. High $\mathrm{N}$ concentration treatments (N102 and N158) resulted in high $\mathrm{N}$ loaded to the environment, 352 to 404 and 741 to $752 \mathrm{~kg} \cdot \mathrm{ha}^{-1} \mathrm{~N}$, respectively (Fig. 3). Conversely, N56 application resulted in much lower $\mathrm{N}$ loading (39 to $104 \mathrm{~kg} \cdot \mathrm{ha}^{-1}$ $\mathrm{N}$ ). The low $\mathrm{N}$ treatment (N9) removed $\mathrm{N}$ from the soil at rates greater than that added, as indicated by the negative values in Figure 3 .

\section{Discussion}

Nitrogen uptake and availability as found in diagnostic leaves and in leaf petioles increased as $\mathrm{N}$ concentration in irrigation solution increased (Table 3). This result is in agreement with Bar-Tal et al. (2001) who reported increased $\mathrm{N}$ uptake when $\mathrm{N}$ concentration in irrigation water rose from 3.5 to 147 $\mathrm{mg} \cdot \mathrm{L}^{-1} \mathrm{~N}$. However, escalation in irrigation $\mathrm{N}$ concentration above N56 was not followed by a significant increase in $\mathrm{N}$ accumulation in plant organs (Table 5). This also is consistent with results found by Bar-Tal et al. (2001) in which no significant increase in $\mathrm{N}$ uptake was observed when irrigation solution concentration was increased from 98 to $147 \mathrm{mg} \cdot \mathrm{L}^{-1} \mathrm{~N}$ for pepper plants grown in an aerohydroponic system. Similar to that found in the present study, no differences in $\mathrm{N}$ uptake were found when pepper plants were irrigated with 150 to $350 \mathrm{~kg} \cdot \mathrm{ha}^{-1} \mathrm{~N}$ in greenhouse-grown peppers in the Jordan Valley (Qawasmi et al., 1999). These results indicate that pepper plants grown under intensive cropping systems and fertigated on a daily basis reach a point where no further increase in $\mathrm{N}$ uptake is observed with 

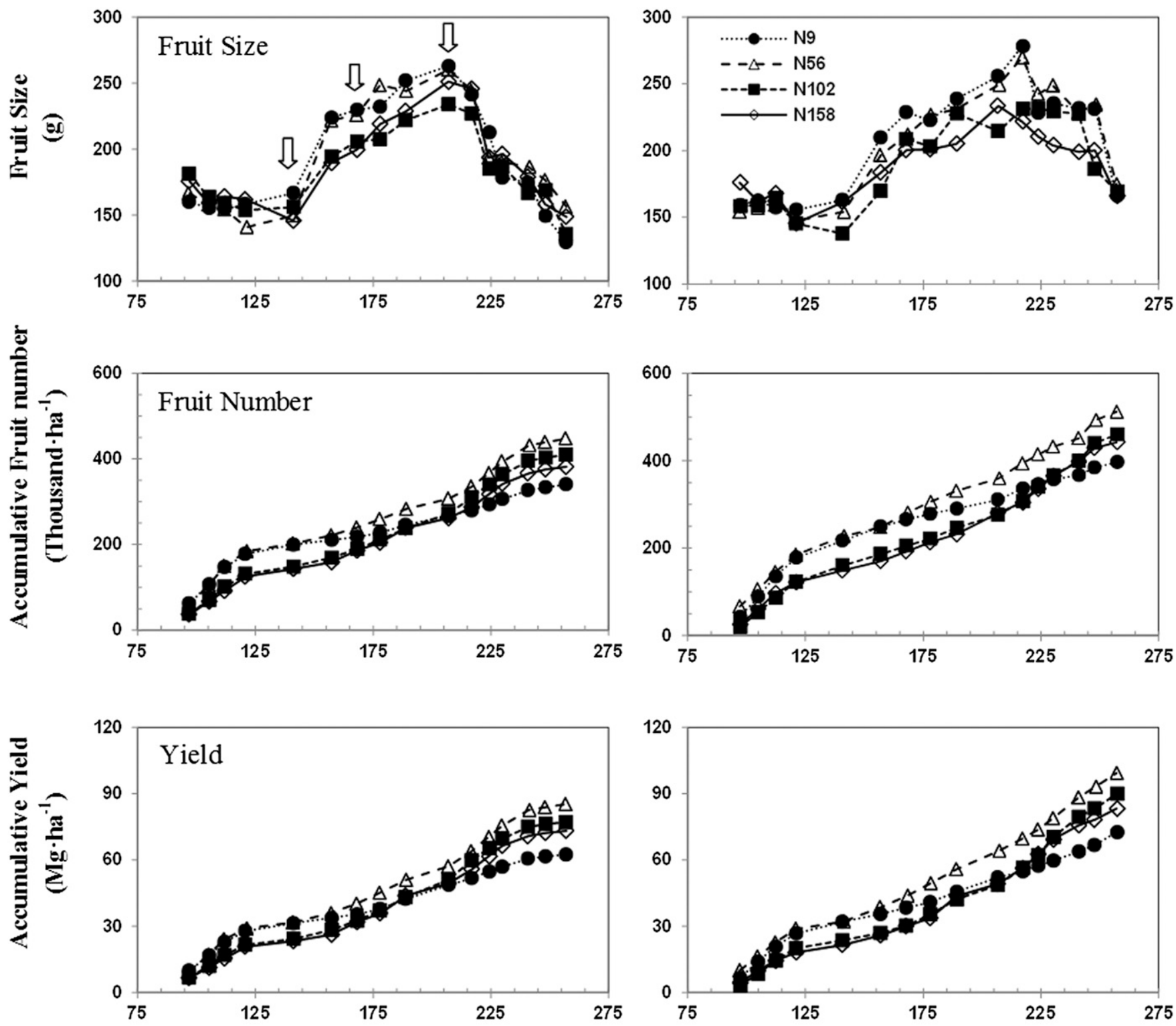

Days after planting

Fig. 1. Influence of nitrogen $(\mathrm{N})$ concentration in irrigation water on fruit size, fruit number, and yield during the season in two cultivars. Pepper plants were irrigated with four levels of $\mathrm{N}$ in the irrigation solution, 9.2, 56.2, 102.3, and $158.5 \mathrm{mg} \cdot \mathrm{L}^{-1} \mathrm{~N}$ (N9, N56, N102, and N158, respectively). Arrows indicate specific harvest dates used for statistical analysis found in Table 6.

increased $\mathrm{N}$ concentration in the irrigation water. Hartz et al. (1993) reported a linear increase in $\mathrm{N}$ uptake rate when pepper plants were grown in the open field in the United States and fertigated with lower N concentrations ( 0 to $336 \mathrm{~kg} \cdot \mathrm{ha}^{-1} \mathrm{~N}$ ). Similarly, in other crops such as white cabbage, carrots, leeks, and broccoli, $\mathrm{N}$ accumulation has been positively correlated with $\mathrm{N}$ rate (Sorensen, 1999). The majority of the studies on peppers were conducted in open fields (Hartz et al., 1993; Olsen et al., 1993) or over a short summer season (Bowen and Frey, 2002). Qawasmi et al. (1999) conducted an experiment in the Jordan Valley over a season similar to that in our study but applied irrigation water on a weekly and not daily basis and used urea as their $\mathrm{N}$ source for fertigation. Both of these could be cause for lower performance and measures of efficiency.

When evaluating $\mathrm{N}$ distribution in the plant, it was found that in all organs sampled except the roots, low $\mathrm{N}$ concentration (N9) in the irrigation solution resulted in a significantly lower accumulation of $\mathrm{N}$ compared with all other $\mathrm{N}$ treatments (Table 5). Fruits accumulate a large portion of the $\mathrm{N}$ taken up by plants (Olsen et al., 1993). Under our experimental conditions, between $32 \%$ and $44 \%$ of the total $\mathrm{N}$ removed by the plants was accumulated in the fruits. This range is lower than that found by Olsen et al. (1993), in which pepper fruit accumulated $40 \%$ to $64 \%$ of total plant $\mathrm{N}$ uptake. These differences might be related to different $\mathrm{N}$ use and distribution patterns between the different cultivars tested or to the differences between pepper plants grown in the open field under plastic mulch (Olsen et al., 1993) compared with plants grown in a large protective structure.

Although $\mathrm{N}$ accumulated to high concentrations in pepper fruits, $\mathrm{NO}_{3}-\mathrm{N}$ level was below detection limits (data not shown). Unlike in pepper, increase in $\mathrm{N}$ rates has been shown to cause increased $\mathrm{NO}_{3}-\mathrm{N}$ accumulation in leafy crops (Sorensen, 1999; Stefanelli et al., 2011). Nitrate accumulation can become a significant problem as a result 
of the possibility of conversion to toxic nitrites during postharvest (Stefanelli et al., 2010). We found a reduction in the proportion of $\mathrm{N}$ accumulated in the fruits as $\mathrm{N}$ concentration increased in the irrigation water (Table 5). This indicates that high $\mathrm{N}$ concentration might promote vegetative growth by allocating $\mathrm{N}$ to vegetative organs (Mengel et al., 2001).

Table 6. Yield component (fruit number and fruit weight) analysis at 141, 168, and $207 \mathrm{~d}$ after planting (DAP) ${ }^{\mathrm{z}}$

\begin{tabular}{|c|c|c|c|c|c|c|c|}
\hline \multirow{2}{*}{\multicolumn{2}{|c|}{ Treatment }} & \multicolumn{3}{|c|}{ Fruit number (thousand/ha) } & \multicolumn{3}{|c|}{ Fruit wt (g/fruit) } \\
\hline & & \multicolumn{6}{|c|}{ DAP } \\
\hline Nitrogen & Cultivar & 141 & 168 & 207 & 141 & 168 & 207 \\
\hline N9 & 7180 & 199 & 218 & 267 & 166.7 & 229.8 & 262.8 \\
\hline N56 & & 202 & 239 & 307 & 149.7 & 225.9 & 260.3 \\
\hline N102 & & 148 & 189 & 272 & 156.1 & 205.8 & 233.8 \\
\hline N158 & & 142 & 186 & 261 & 145.8 & 199.4 & 251.0 \\
\hline N9 & 7182 & 203 & 232 & 290 & 163.0 & 228.6 & 255.7 \\
\hline N56 & & 209 & 267 & 355 & 153.9 & 211.7 & 249.1 \\
\hline N102 & & 153 & 188 & 273 & 137.8 & 208.6 & 214.4 \\
\hline N158 & & 134 & 178 & 269 & 161.6 & 200.4 & 233.5 \\
\hline \multicolumn{8}{|l|}{ Nitrogen } \\
\hline N9 & & $201 \mathrm{~A}$ & $225 \mathrm{~B}$ & $278 \mathrm{~B}$ & $164.9 \mathrm{~A}$ & $229.2 \mathrm{~A}$ & $259.8 \mathrm{~A}$ \\
\hline N56 & & $205 \mathrm{~A}$ & $253 \mathrm{~A}$ & $331 \mathrm{~A}$ & $151.8 \mathrm{~A}$ & $218.8 \mathrm{AB}$ & $254.7 \mathrm{AB}$ \\
\hline N102 & & $151 \mathrm{~B}$ & $188 \mathrm{C}$ & $273 \mathrm{~B}$ & $146.9 \mathrm{~A}$ & $207.2 \mathrm{AB}$ & $224.1 \mathrm{~B}$ \\
\hline N158 & & $138 \mathrm{~B}$ & $182 \mathrm{C}$ & $265 \mathrm{~B}$ & $153.7 \mathrm{~A}$ & 199.9 B & $242.3 \mathrm{AB}$ \\
\hline \multicolumn{8}{|l|}{ Cultivar } \\
\hline 7180 & & $173 \mathrm{~A}$ & $208 \mathrm{~A}$ & $277 \mathrm{~A}$ & $154.6 \mathrm{~A}$ & $215.2 \mathrm{~A}$ & $252.3 \mathrm{~A}$ \\
\hline 7182 & & $175 \mathrm{~A}$ & $216 \mathrm{~A}$ & $297 \mathrm{~A}$ & $154.1 \mathrm{~A}$ & $212.3 \mathrm{~A}$ & $238.2 \mathrm{~B}$ \\
\hline Nitrogen $>$ & ltivar & NS & NS & NS & NS & NS & NS \\
\hline
\end{tabular}

Table 7. Nitrogen $(\mathrm{N})$ effect on fruit physical and chemical properties at $168 \mathrm{~d}$ after planting. ${ }^{.}$

\begin{tabular}{|c|c|c|c|c|c|c|c|c|}
\hline \multicolumn{2}{|c|}{ Treatment } & \multirow{2}{*}{$\begin{array}{c}\text { Fruit avg } \\
\text { wt }(g)\end{array}$} & \multirow{2}{*}{$\begin{array}{l}\text { Seed wt } \\
\text { (g/fruit) }\end{array}$} & \multirow{2}{*}{$\begin{array}{c}\text { Pericarp } \\
\text { width }(\mathrm{mm})\end{array}$} & \multirow{2}{*}{$\begin{array}{c}\text { TSS } \\
\left({ }^{\circ} \text { Brix }\right)\end{array}$} & \multirow{2}{*}{$\begin{array}{l}\text { Glucose } \\
\left(\mathrm{mg} \cdot \mathrm{dL}^{-1}\right)\end{array}$} & \multirow[b]{2}{*}{$\mathrm{pH}$} & \multirow{2}{*}{$\begin{array}{l}\text { Acidity citric } \\
\text { acid (mM) }\end{array}$} \\
\hline Nitrogen & $\overline{\text { Cultivar }}$ & & & & & & & \\
\hline$\overline{\text { N9 }}$ & 7180 & 250 & 4.3 & 6.2 & 7.6 & 4765 & 4.77 & 13.3 \\
\hline N56 & & 239 & 4.6 & 6.2 & 7.6 & 5053 & 4.72 & 13.6 \\
\hline N102 & & 255 & 5.0 & 6.4 & 7.7 & 5120 & 4.79 & 12.7 \\
\hline N158 & & 245 & 4.5 & 6.6 & 7.5 & 4855 & 4.83 & 13.3 \\
\hline N9 & 7182 & 250 & 4.5 & 6.9 & 7.8 & 5445 & 4.79 & 14.9 \\
\hline N56 & & 222 & 3.7 & 6.5 & 8.1 & 5150 & 4.78 & 15.0 \\
\hline N102 & & 235 & 3.7 & 6.3 & 7.8 & 5420 & 4.86 & 14.9 \\
\hline N158 & & 250 & 4.8 & 6.9 & 8.0 & 5340 & 4.80 & 14.0 \\
\hline Nitrogen & & & & & & & & \\
\hline $\begin{array}{l}\text { Cultivar } \\
\text { Nitrogen } \times \\
\text { cultivar }\end{array}$ & & NS & NS & NS & NS & NS & NS & NS \\
\hline
\end{tabular}

${ }^{2}$ Pepper plants were irrigated with four levels of $\mathrm{N}$ in the irrigation solution, $9.2,56.2,102.3$, and $158.5 \mathrm{mg} \cdot \mathrm{L}^{-1}$ N (N9, N56, N102, and N158, respectively). Properties were analyzed by two-way analysis of variance with JMP 10.0 software (SAS Institute Inc., Cary, NC). Default significance levels were set at $\alpha=0.05$.

TSS $=$ total soluble solids.

NS $=$ nonsignificant.

In the present study, pepper plant vegetative growth (as measured by plant height and shoot fresh weight; Table 4) did not respond to increases in irrigation solution $\mathrm{N}$ concentration above $56.2 \mathrm{mg} \cdot \mathrm{L}^{-1} \mathrm{~N}$. Additional vegetative growth in response to elevated $\mathrm{N}$ concentration is often reported in other crops such as processing tomato (Elia and Conversa, 2012; Tei et al., 2002). Similarly to our data, Bar-Tal et al. (2001) found that $\mathrm{N}$ concentration above $98 \mathrm{mg} \cdot \mathrm{L}^{-1}$ did not increase pepper stem, leaf, or fruit weight, and that high $\mathrm{N}$ concentration $\left(196 \mathrm{mg} \cdot \mathrm{L}^{-1} \mathrm{~N}\right)$ resulted in reduction of plant organ biomass. The fact that high $\mathrm{N}$ treatments were characterized with fewer ripe fruits in the beginning of the season (Fig. 1; Table 6) might indicate that high $\mathrm{N}$ level promoted vegetative growth at the expense of fruit production (Mengel et al., 2001). The lack of a positive yield response to increasing N from N56 to N158 is consistent with several other studies that found that low $\mathrm{N}$ application $\left(252 \mathrm{~kg} \cdot \mathrm{ha}^{-1}\right.$ $\mathrm{N})$ was sufficient for optimal fruit production of pepper plants (Bowen and Frey, 2002; Hartz et al., 1993; Qawasmi et al., 1999). An additional study did indicate positive effects of $\mathrm{N}$ fertilization on pepper productivity related to an increase in chlorophyll content and improved light use efficiency (Candido et al., 2009). Although pepper plants in Candido et al. (2009) had enhanced vegetative growth as a function of $\mathrm{N}$ rate, their fruit yield response was comparable to that found in our experiment. Similar to what we found in pepper, an increased $\mathrm{N}$ rate above optimal resulted in yield reduction in tomato (Elia and Conversa, 2012). Like in our results (Fig. 1), tomato plant response to high $\mathrm{N}$ application was manifested by a reduction in fruit number. This information emphasizes the important role $\mathrm{N}$ plays in plant developmental processes.

No significant effect of $\mathrm{N}$ concentration in the irrigation solution on fruit quality parameters was found (Tables 7 and 8; Supplemental Tables S2 and S3, available online). This is contrary to Candido et al. (2009) who reported increased fruit weight and reduction in TSS as N concentration increased. Unlike our findings for pepper, reduction in $\mathrm{N}$ concentration resulted in increased organoleptic fruit

Table 8. Nitrogen $(\mathrm{N})$ effect on fruit nutritional properties at $168 \mathrm{~d}$ after planting. ${ }^{2}$

\begin{tabular}{|c|c|c|c|c|c|c|}
\hline \multicolumn{2}{|c|}{ Treatment } & \multirow{2}{*}{$\begin{array}{c}\text { Water } \\
\text { content (\%) }\end{array}$} & \multirow{2}{*}{$\begin{array}{c}\text { FRAP ascorbic } \\
\text { acid equivalence }(\mu \mathrm{M})\end{array}$} & \multirow{2}{*}{$\begin{array}{c}\text { ORAC ascorbic acid } \\
\text { equivalence }(\mu \mathrm{M})\end{array}$} & \multirow{2}{*}{$\begin{array}{c}\beta \text {-carotene } \\
(\mathrm{mg} / 100 \mathrm{~mL})\end{array}$} & \multirow{2}{*}{$\begin{array}{c}\text { Lycopene } \\
(\mathrm{mg} / 100 \mathrm{~mL})\end{array}$} \\
\hline Nitrogen & Cultivar & & & & & \\
\hline N9 & 7180 & 90.7 & 3.7 & 21.1 & 2.3 & 1.1 \\
\hline N56 & & 90.9 & 3.8 & 19.5 & 2.8 & 1.3 \\
\hline N158 & & 90.5 & 3.4 & 20.9 & 2.7 & 1.3 \\
\hline N9 & 7182 & 91.2 & 4.2 & 17.1 & 3.8 & 1.7 \\
\hline N56 & & 91.4 & 3.7 & 19.8 & 3.1 & 1.5 \\
\hline N102 & & 91.1 & 5.0 & 20.9 & 2.8 & 1.4 \\
\hline Cultivar & & NS & NS & NS & NS & NS \\
\hline
\end{tabular}

Nitrogen $\times$ cultivar

${ }^{2}$ Pepper plants were irrigated with four levels of $\mathrm{N}$ in the irrigation solution, 9.2, 56.2, 102.3, and $158.5 \mathrm{mg} \cdot \mathrm{L}^{-1} \mathrm{~N}$ (N9, N56, N102, and N158, respectively). Properties were analyzed by two-way analysis of variance with JMP 10.0 software (SAS Institute Inc., Cary, NC). Default significance levels were set at $\alpha=0.05$. FRAP $=$ ferric reducing antioxidant capacity; ORAC $=$ oxygen radical absorption capacity.

$\mathrm{NS}=$ nonsignificant. 


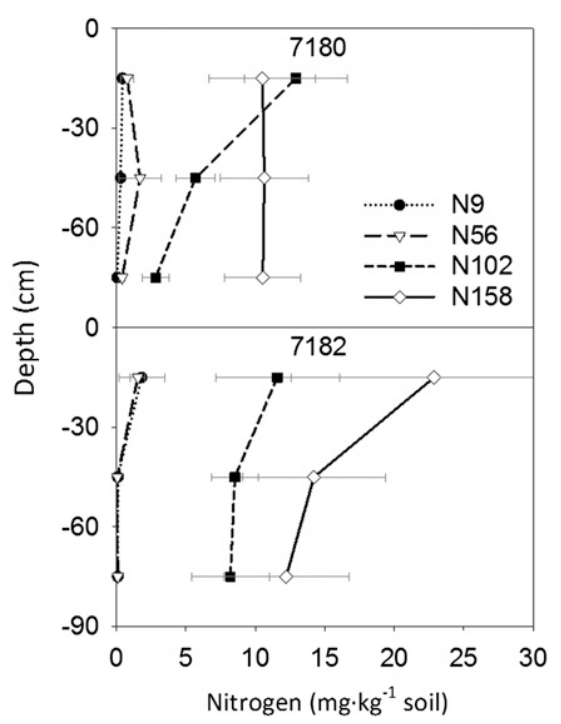

Fig. 2. Mineral nitrogen $(\mathrm{N})$ in soil profile after the last harvest. Pepper plants from two the cultivars were irrigated with four levels of $\mathrm{N}$ in the irrigation solution, 9.2, 56.2, 102.3 and 158.5 $\mathrm{mg} \cdot \mathrm{L}^{-1} \mathrm{~N}$ (N9, N56, N102, and N158, respectively). Bars represent SEM.

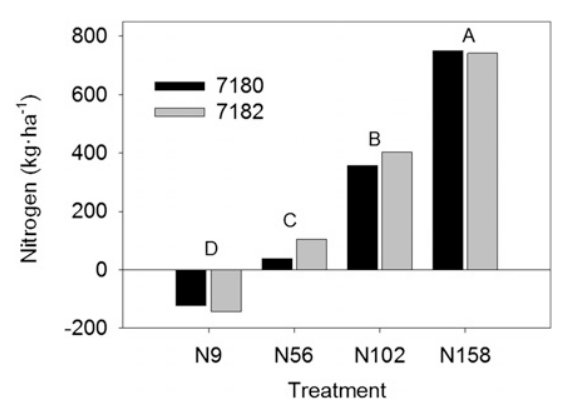

Fig. 3. Nitrogen $(\mathrm{N})$ loaded to the environment as a function of $\mathrm{N}$ concentration in fertilizer; no significant differences were found between the cultivars according to Tukey's honestly significant difference (HSD) analysis $(P=0.05)$. Pepper plants were irrigated with four levels of $\mathrm{N}$ in the irrigation solution, 9.2, 56.2, 102.3, and $158.5 \mathrm{mg} \cdot \mathrm{L}^{-1} \mathrm{~N}(\mathrm{~N} 9, \mathrm{~N} 56, \mathrm{~N} 102$, and N158, respectively). Treatments accompanied with the same letter are not significantly different according to Tukey's HSD two-way analyses of variance $(P \leq 0.05)$.

quality of tomato, characterized by fruit with lower acidity and higher soluble sugars (Bénard et al., 2009; Dorias and Papadopoulos, 2001). The lack of influence of irrigation water $\mathrm{N}$ concentration on the total antioxidant capacity was correlated with the accumulation of pigments (serving as major antioxidant agents) in the pepper fruits (Table 8; Supplemental Table S3, available online). These findings contradict those found by Flores et al. (2004) who compared different $\mathrm{NO}_{3}-\mathrm{N}$ fertilization concentrations on nutritional quality of pepper fruits. Those authors found an increase in antioxidant and pigment content after increasing $\mathrm{N}$ fertilization. On the other hand, Del Amor (2007) reported a negative correlation between $\mathrm{N}$ concentration and antioxidant content in pepper. The observed reduction in the concentrations of bioactive and nutritional substances can be explained by "dilution effects." The lack of response to increased $\mathrm{N}$ concentration in our experiment might be the result of the differences in $\mathrm{N}$ concentrations applied and the hydroponic system used in Del Amor's (2007) experiments as compared with our cultivation in sandy soil. The solution of the two high $\mathrm{N}$ treatments contained considerable concentrations of $\mathrm{NH}_{4}-\mathrm{N}$ (Table 1), which according to Bar-Tal et al. (2001) might be high enough to have negative effects on fruit quality when grown in soilless culture characterized with low $\mathrm{pH}$ buffer capacity. We are confident that the regime of irrigating daily and cultivation in soil assures that the $\mathrm{NH}_{4}-\mathrm{N}$ applied in the current experiment can safely be assumed to be nitrified and taken up by the plants as nitrate.

Elevated $\mathrm{N}$ levels found in the soil profile as a result of high $\mathrm{N}$ irrigation water concentrations (N102 and N158 treatments; Fig. 2) have the potential to negatively affect the environment (Fig. 3). The $\mathrm{NO}_{3}-\mathrm{N}$ in the soil might easily be leached with future irrigation or rain water and eventually contaminate groundwater. Similar results have been found for a hot pepper (C. frutescens L.) cropping system in northeast China (Zhu et al., 2005) where increase in $\mathrm{N}$ concentration led to higher mineral $\mathrm{N}$ in the soil profile, which, in turn, led to $\mathrm{NO}_{3}-\mathrm{N}$ leaching to deeper soil layers and groundwater. Increase of $\mathrm{N}$ concentration from 120 to $175 \mathrm{mg} \cdot \mathrm{L}^{-1}$ resulted in 2.5- to 3.5-fold increases in leachate $\mathrm{NO}_{3}-\mathrm{N}$ concentration for pepper grown on rockwool (Schon et al., 1994). Likewise, for tomato grown on a sandy soil, $\mathrm{N}$ application above $220 \mathrm{~kg} \cdot \mathrm{ha}^{-1}$ did not bring about agronomic benefits but substantially increased $\mathrm{NO}_{3}-\mathrm{N}$ leaching (Zotarelli et al., 2009). In southeastern China, $\mathrm{NO}_{3}-\mathrm{N}$ leaching was found to be the primary $\mathrm{N}$ loss pathway at high $\mathrm{N}$ application rates in greenhouse vegetable cropping systems (Min et al., 2011). Nitrate leaching and contamination of groundwater are expected to be even more problematic when vegetable crops are irrigated with the high leaching factors necessary for successful use of water containing high concentrations of salts (BenGal et al., 2008).

The high environmental NUE found in the low $\mathrm{N}$ concentration treatment (N9, Table 5) might be the result of $\mathrm{N}$ mineralization from soil. However, the significantly lower fruit yield found in this compared with the other $\mathrm{N}$ treatments (Table 4) indicates an overall deficiency. Similar reduction in environmental NUE as $\mathrm{N}$ concentration increased was found when pepper plants were grown either in the open field or in unheated greenhouses (Candido et al., 2009; Van Eerd, 2007). We demonstrate here that by reducing $\mathrm{N}$ concentration from 102.3 to $56.2 \mathrm{mg} \cdot \mathrm{L}^{-1}$, environmental NUE could be increased from $\approx 50 \%$ to nearly $90 \%$ (Table 5). This high efficiency is much greater than the $50 \%$ commonly reported for other agronomic crops (Fageria and Baligar, 2005). The increase in $\mathrm{N}$ con- centration in the irrigation solution reduced environmental NUE up to $38 \%$ at the high $\mathrm{N}$ concentration (Table 5). We suggest that the superior efficiencies found in the current study can be credited to provision of temporal $\mathrm{N}$ required by the crop, made possible by fertilizer application through the drip irrigation system.

Use of plant species or genotypes efficient in absorption and use of $\mathrm{N}$ is an important strategy for improving NUE and sustainable agricultural systems (Fageria and Baligar, 2005; Mascleaux-Daubresse et al., 2010). Fruit production NUE, agronomic NUE, and plant production NUE demonstrate that the two cultivars used in this study differ in their NUE. The vigorous cultivar 7182 produced $40 \mathrm{~kg}$ more fruit for each kilogram of $\mathrm{N}$ applied or taken up by the plants compared with cultivar 7180 (Table 5). Genetic variability in NUE has been known for many years regarding grain crops (Smith, 1934). Genetic variation for NUE has been categorized into differences in uptake and use of $\mathrm{N}$. In tomato, genotype variation influenced $\mathrm{N}$ use and assimilation (Ruiz and Romero, 1998). Nitrate reductase catalyzes the reduction of nitrate to nitrite and is considered a limiting factor in growth and development of plants. In tomato, differences in NUE between genotypes were related to differences in nitrate reductase activity, amino acids and proteins biosynthesis, and the accumulation of nitrate and organic $\mathrm{N}$ in leaf tissue (Ruiz and Romero, 1998). In our experiment, no significant differences in $\mathrm{N}$ uptake were found between the cultivars; however, the vigorous cultivar was able to use $\mathrm{N}$ more efficiently and to convert this input into fruit yield (Tables 4 and 5). Future work is needed to determine mechanisms responsible for the differences between the pepper cultivars.

\section{Conclusions}

For unheated greenhouse-grown bell pepper with a summer-spring cycle, the highest yields were obtained when pepper plants were fertilized with $56.2 \mathrm{mg} \cdot \mathrm{L}^{-1} \mathrm{~N}$ throughout the growing season. Further increase in $\mathrm{N}$ concentration resulted in yield reduction attributable to reduction in fruit number at the beginning of the season. Nitrogen fertilizer concentration did not affect fruit quality or fruit nutritional value. High N concentrations (N102 and N158) resulted in augmented $\mathrm{N}$ levels in soil layers below the active rooting zone. Pepper cultivars differed in their NUE as a result of differential fruit production as a function of either $\mathrm{N}$ supply or $\mathrm{N}$ taken up by the plants. Reduced $\mathrm{N}$ concentration and use of a pepper cultivar with improved NUE minimized the environmental impact of $\mathrm{N}$ without harming fruit yield or quality.

\section{Supplementary data}

Supplementary data are available online and consist of Table S1: Plant organ dry matter yield (g/plant) and dry matter content 
(\%) and their statistical analysis; Table S2: Nitrogen effects on fruit physical and chemical properties at 207 DAP and statistical analysis; Table S3: Nitrogen effects on fruit nutritional properties at 207 DAP and statistic analysis.

\section{Literature Cited}

Barker, A.V. and G.M. Bryson. 2007. Handbook of plant nutrition. CRC Press, Boca Raton, FL.

Bar-Tal, A., B. Aloni, L. Karni, and R. Rosenberg. 2001. Nitrogen nutrition of greenhouse pepper. II. Effect of nitrogen concentration and $\mathrm{NO}_{3}$ : $\mathrm{NH}_{4}$ ratio on growth, transpiration, and nutrient uptake. HortScience 36:1252-1259.

Bénard, C., H. Gautier, F. Bourgaud, D. Grasselly, B. Navez, C. Caris-Veyrat, M. Weiss, and M. Génard. 2009. Effect of low nitrogen supply on tomato (Solanum lycopersicum) fruit yield and quality with special emphasis on sugars, acids, ascorbate, carotenoids, and phenolic compounds. J. Agr. Food Chem. 57:41124123.

Ben-Gal, A., E. Ityel, L. Dudley, S. Cohen, U. Yermiyahu, E. Presnov, L. Zigmond, and U. Shani. 2008. Effect of irrigation water salinity on transpiration and on leaching requirements: A case study for bell peppers. Agr. Water Mgt. 95:587-597.

Benzie, I.F.F. and J.J. Strain. 1996. The ferric reducing ability of plasma (FRAP) as a measure of 'antioxidant power': The FRAP assay. Anal. Biochem. 239:70-76.

Bowen, P. and B. Frey. 2002. Response of plasticultured bell pepper to staking, irrigation frequency, and fertigated nitrogen rate. HortScience 37:95100.

Butera, D., L. Tesoriere, F. Di Gaudio, A. Bongiorno, M. Allegra, A.M. Pintaudi, R. Kohen, and M.A. Livrea. 2002. Antioxidant activities of sicilian prickly pear (Opuntia ficus indica) fruit extracts and reducing properties of its betalains: Betanin and indicaxanthin. J. Agr. Food Chem. 50:68956901.

Byers, T. and G. Perry. 1992. Dietary carotenes, vitamin $C$, and vitamin $E$ as protective antioxidants in human cancers. Annu. Rev. Nutr. 12:139-159.

Candido, V., V. Miccolis, and A.R. Rivelli. 2009 Yield traits and water and nitrogen use efficiencies of bell pepper grown in plastic-greenhouse. Ital. J. of Agron. 3:91-100.

Del Amor, F.M. 2007. Yield and fruit quality response of sweet pepper to organic and mineral fertilization. Renew. Agr. Food Sys. 22:233-238.

Dorias, M. and A.P. Papadopoulos. 2001. Greenhouse tomato fruit quality. Hort. Rev. 26:239-319.

Elia, A. and G. Conversa. 2012. Agronomic and physiological responses of a tomato crop to nitrogen input. Eur. J. Agron. 40:64-74.

Fageria, N.K. and V.C. Baligar. 2005. Enhancing nitrogen use efficiency in crop plants. Adv. Agron. 88:97-185.
Flores, P., J.M. Navarro, C. Garrido, J.S. Ribio, and V. Martínez. 2004. Influence of $\mathrm{Ca}^{2+}, \mathrm{K}^{+}$and $\mathrm{NO}_{3}{ }^{-}$fertilisation on nutritional quality of pepper. J. Sci. Food Agr. 84:569-574.

Gastal, F. and G.N. Lemaire. 2002. N uptake and distribution in crops: An agronomical and ecophysiological perspective. J. Expt. Bot. 53: 789-799.

Glass, A.D.M. 2003. Nitrogen use efficiency of crop plant: Physiological constraints upon nitrogen absorption. Crit. Rev. Plant Sci. 22:453470.

Gruda, N. 2005. Impact of environmental factors on product quality of greenhouse vegetables for fresh consumption. Crit. Rev. Plant Sci. 24:227-247.

Hartz, T.K., M. Lestrange, and D.M. May. 1993. Nitrogen requirements of drip-irrigated pepper. HortScience 28:1097-1099.

Howard, L.R., S.T. Talcott, C.H. Brenes, and B. Villalon. 2000. Changes in phytochemical and antioxidant activity of selected pepper cultivars (Capsicum species) as influenced by maturity. J. Agr. Food Chem. 48:1713-1720.

Jovicich, E., D.J. Cantliffe, and P.S. Stoffella. 2004. Fruit yield and quality of greenhousegrown bell pepper as influenced by density, container, and trellis system. HortTechnology 14:507-513.

Masclaux-Daubresse, C., F. Daniel-Vedele, J. Dechorgnat, F. Chardon, L. Gaufichon, and A. Suzuki. 2010. Nitrogen uptake, assimilation and remobilization in plants: challenges for sustainable and productive agriculture. Ann. Bot. 105:1141-1157.

Mengel, K., E.A. Kirkby, H. Kosegarten, and T. Appel. 2001. Principles of plant nutrition. Kluwer Academic Publisher, Dordrecht, The Netherlands.

Min, J., X. Zhao, W.M. Shi, G.X. Xing, and Z.L. Zhu. 2011. Nitrogen balance and loss in greenhouse vegetable system in southeastern China. Pedosphere 21:464-472.

Nagata, M. and I. Yamashita. 1992. Simple method for simultaneous determination of chlorophyll and carotenoids in tomato fruit.. J. Jap. Soc. for Food Sci. Technol. 39:925-928.

Olsen, J.K., P.J. Lyons, and M.M. Kelly. 1993. Nitrogen uptake and utilization by bell pepper in subtropical Australia. J. Plant Nutr. 16: 2055-2071.

Pierzynski, G.M. 2000. Methods of phosphorus analysis for soils, sediments, residuals, and waters. North Carolina State University, Raleigh, NC.

Prior, R.L., H. Hoang, L. Gu, X. Wu, M. Bacchiocca, L. Howard, M. Hampsch-Woodill, D. Huang, B. Ou, and R. Jacob. 2003. Assays for hydrophilic and lipophilic antioxidant capacity (oxygen radical absorbance capacity [ORAC $\mathrm{FL}_{\mathrm{FL}}$ ) of plasma and other biological and food samples. J. Agr. Food Chem. 51:3273-3279.

Qawasmi, W., M.J. Mohammad, H. Najim, and R. Qubursi. 1999. Response of bell pepper grown inside plastic houses to nitrogen fertigation. Comm. in Soil Sci. Plant Anal. 30:2499-2509.

Raveh, E., T. Saban, Z. Hillman, and E. BeitYannai. 2009. Influence of rootstock and scion on antioxidant capacity of juice from new pomelo and mandarin varieties. J. Sci. Food Agr. 89:1825-1830.

Ruiz, J.M. and L. Romero. 1998. Tomato genotype in relation to nitrogen utilization and yield. J. Agr. Food Chem. 46:4420-4422.

Schon, M.K., M.P. Compton, E. Bell, and I. Burns. 1994. Nitrogen concentrations affect pepper yield and leachate nitrate-nitrogen from rockwool culture. HortScience 29:1139-1142.

Segal, E., A. Dag, A. Ben-Gal, I. Zipori, R. Erel, S Suryano, and U. Yermiyahu. 2011. Olive orchard irrigation with reclaimed wastewater: Agronomic and environmental considerations. Agr. Ecosyst. Environ. 140:454-461.

Smith, N. 1934. Response of inbred lines and crosses in maize to variations of nitrogen and phosphorus supplied as nutrients. J. Amer. Soc. Agron. 26:785-804.

Snell, F.D. and C.T. Snell. 1949. Colorimetric methods analysis including some turbidimetic and nephelometric methods. Vol. 2. Inorganic. Van Nostrand, Toronto, Canada.

Sorensen, J.N. 1999. Nitrogen effects on vegetable crop production and chemical composition. Acta Hort. 506:41-49.

Stefanelli, D., I. Goodwin, and R. Jones. 2010 Minimal nitrogen and water use in horticulture: Effect on quality and content of selected nutrients. Food Res. Intl. 43:1833-1843.

Stefanelli, D., S. Winkler, and R. Jones. 2011. Reduced nitrogen availability during growth improves quality in red oak lettuce leaves by minimizing nitrate content, and increasing antioxidant capacity and leaf mineral content. Agr. Sci. 2:477-486.

Strong, D.T., P.W.G. Sale, and K.R. Helyar. 1999. The influence of the soil matrix on nitrogen mineralisation and nitrification. Aust. J. Soil Res. 37:329-350.

Tanny, J., S. Cohen, and M. Teitel. 2003. Screenhouse microclimate and ventilation: An experimental study. Biosys. Eng. 80:331-341.

Tei, F., P. Benincasa, and M. Guiducci. 2002. Critical nitrogen concentration in processing tomato. Eur. J. Agron. 18:45-55.

Van Eerd, L.L. 2007. Evaluation of different nitrogen use efficiency indices using fieldgrown green peppers (Capsicum annuum L.). Can. J. Plant Sci. 87:565-569.

Zhu, J.H., X.L. Li, P. Christie, and J.L. Li. 2005. Environmental implications of low nitrogen use efficiency in excessively fertilized hot pepper (Capsicum frutescent $\mathrm{L}$.) cropping system. Agr. Ecosyst. Environ. 111:70-80.

Zotarelli, L., M.D. Dukes, J.M.S. Scholberg, R. Munoz-Carpena, and J. Icerman. 2009. Tomato nitrogen accumulation and fertilizer use efficiency on a sandy soil, as affected by nitrogen rate and irrigation scheduling. Agr. Water Mgt. 96:1247-1258 
Table S1. Plant organ dry matter yield and dry matter content $(\%)^{z}$

\begin{tabular}{|c|c|c|c|c|c|c|c|c|c|c|}
\hline \multicolumn{2}{|c|}{ Treatment } & \multicolumn{5}{|c|}{ Plant organ dry weight ( $\mathrm{g} / \mathrm{plant})$} & \multicolumn{4}{|c|}{ Dry weight content (\%) } \\
\hline Nitrogen & Cultivar & Stem & Leaf & Fruit & Root & Total & Stem & Leaf & Fruit & Root \\
\hline N56 & & 205.3 & 121.7 & 253.8 & 37.3 & 580.9 & 18.8 & 14.2 & 9.1 & 20.3 \\
\hline N9 & 7182 & 145.2 & 81.1 & 213.5 & 24.0 & 439.7 & 19.8 & 14.0 & 8.8 & 16.8 \\
\hline N56 & & 196.7 & 99.3 & 285.6 & 35.1 & 581.7 & 19.1 & 13.0 & 8.6 & 18.9 \\
\hline \multicolumn{11}{|l|}{ Nitrogen } \\
\hline N9 & & $153.1 \mathrm{~A}$ & $81.2 \mathrm{~A}$ & $203.4 \mathrm{C}$ & $30.4 \mathrm{~A}$ & $437.7 \mathrm{~B}$ & $20.2 \mathrm{~A}$ & $14.0 \mathrm{~A}$ & $9.1 \mathrm{~A}$ & $19.1 \mathrm{~A}$ \\
\hline N56 & & $201.0 \mathrm{~A}$ & $110.5 \mathrm{~A}$ & $269.7 \mathrm{~A}$ & $36.2 \mathrm{~A}$ & $581.3 \mathrm{~A}$ & $18.9 \mathrm{~B}$ & $13.6 \mathrm{~A}$ & $8.8 \mathrm{~A}$ & $19.6 \mathrm{~A}$ \\
\hline N102 & & 194.6 A & $112.8 \mathrm{~A}$ & $250.4 \mathrm{AB}$ & $33.6 \mathrm{~A}$ & $557.5 \mathrm{~A}$ & $18.1 \mathrm{~B}$ & $13.2 \mathrm{~A}$ & $9.0 \mathrm{~A}$ & $20.1 \mathrm{~A}$ \\
\hline N158 & & $208.4 \mathrm{~A}$ & $113.1 \mathrm{~A}$ & $239.8 \mathrm{AB}$ & $41.1 \mathrm{~A}$ & $561.3 \mathrm{~A}$ & $17.9 \mathrm{~B}$ & $13.3 \mathrm{~A}$ & $9.2 \mathrm{~A}$ & $19.2 \mathrm{~A}$ \\
\hline \multicolumn{11}{|l|}{ Cultivar } \\
\hline
\end{tabular}

${ }^{z}$ Treatments accompanied with the same letter are not significantly different according to Tukey's honestly significant difference two-way analysis of variance with JMP 10.0 software (SAS Institute Inc., Cary, NC). Data present is the averages of four plants from each treatment. Default significance levels were set at $\alpha=0.05$. NS = nonsignificant.

Table S2. Nitrogen (N) effects on fruit physical and chemical properties at $207 \mathrm{~d}$ after planting. ${ }^{\mathrm{z}}$

\begin{tabular}{|c|c|c|c|c|c|c|c|c|}
\hline \multicolumn{2}{|c|}{ Treatment } & \multirow{2}{*}{$\begin{array}{c}\text { Fruit avg } \\
\text { wt (g) }\end{array}$} & \multirow{2}{*}{$\begin{array}{l}\text { Seed wt } \\
\text { (g/fruit) }\end{array}$} & \multirow{2}{*}{$\begin{array}{c}\text { Pericarp } \\
\text { width }(\mathrm{mm})\end{array}$} & \multirow{2}{*}{$\begin{array}{c}\text { TSS } \\
\left({ }^{\circ} \text { Brix }\right)\end{array}$} & \multirow{2}{*}{$\begin{array}{c}\text { Glucose } \\
\left(\mathrm{mg} \cdot \mathrm{dL}^{-1}\right)\end{array}$} & \multirow[b]{2}{*}{$\mathrm{pH}$} & \multirow{2}{*}{$\begin{array}{c}\text { Acidity citric } \\
\text { acid (mM) }\end{array}$} \\
\hline Nitrogen & Cultivar & & & & & & & \\
\hline N56 & & 288 & 5.1 & 6.6 & 7.5 & 4595 & 4.78 & 12.7 \\
\hline N9 & 7182 & 289 & 4.7 & 6.0 & 8.2 & 4345 & 4.51 & 13.2 \\
\hline N56 & & 307 & 5.1 & 6.8 & 8.1 & 4965 & 4.71 & 13.5 \\
\hline N102 & & 304 & 4.7 & 7.0 & 8.3 & 5090 & 4.63 & 13.4 \\
\hline $\begin{array}{l}\text { Nitrogen } \\
\text { Cultivar } \\
\text { Nitrogen }\end{array}$ & & NS & NS & NS & NS & NS & NS & NS \\
\hline
\end{tabular}

${ }^{2}$ Pepper plants were irrigated with four levels of $\mathrm{N}$ in the irrigation solution, 9.2, 56.2, 102.3, and $158.5 \mathrm{mg} \cdot \mathrm{L}^{-1} \mathrm{~N}$ (N9, N56, N102, and N158, respectively). Properties were analyzed by two-way analysis of variance with JMP 10.0 software (SAS Institute Inc., Cary, NC). Default significance levels were set at $\alpha=0.05$. TSS $=$ total soluble solids.

$\mathrm{NS}=$ nonsignificant.

Table S3. Nitrogen (N) effects on fruit nutritional properties at $207 \mathrm{~d}$ after planting. ${ }^{\mathrm{z}}$

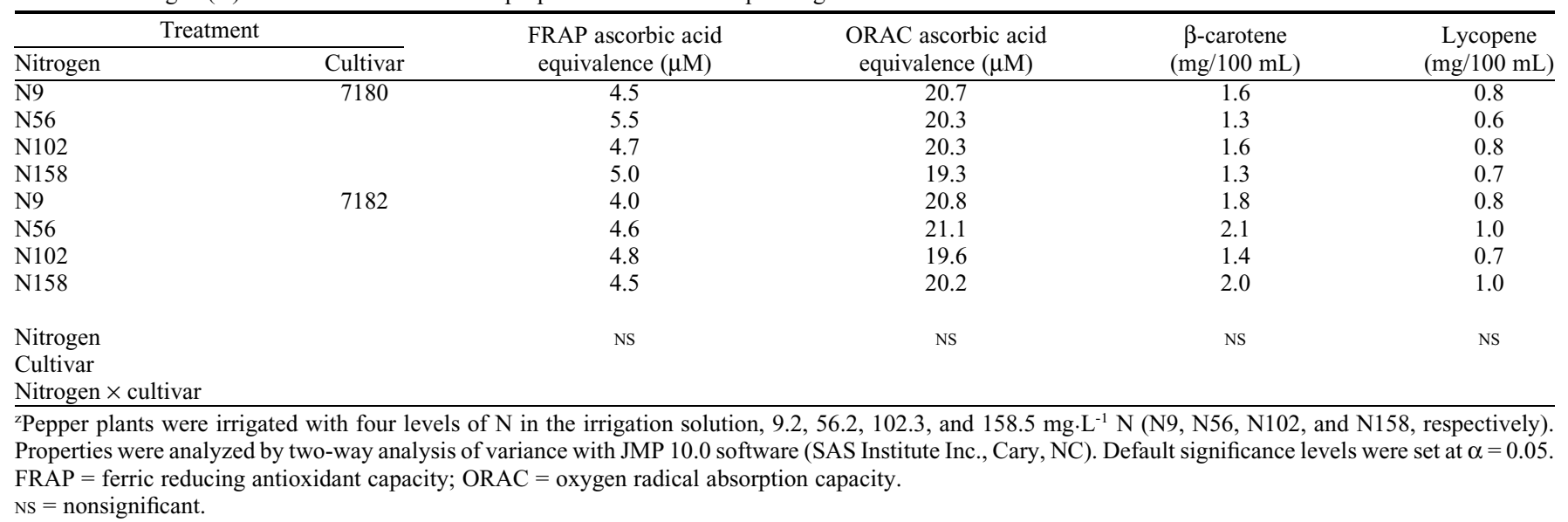

